\title{
Perspektif Multikultur, Kasus Film 3 Hati 2 Dunia 1 Cinta
}

\author{
Maria Nala Damayanti \\ Jurusan Desain Komunikasi Visual, Fakultas Seni dan Desain \\ Universitas Kristen Petra, Surabaya, Indonesia \\ Email: mayadki@petra.ac.id
}

\begin{abstract}
Abstrak
Isu multikultur di Indonesia adalah wacana baru dalam budaya yang penting sehubungan dengan banyak konflik SARA yang terjadi akhir-akhir ini. Film sebagai media audio visual punya peranan besar dalam mengkampanyekan ide tersebut. Oleh karena itu menganalisa film dengan perspektif multikultur akan menjadi pandangan tersendiri yang mungkin dikembangkan dalam kaitannya dengan peranannya dalam kemajemukan budaya. Artikel ini mengulas film '3 Hati 2 Dunia 1 Cinta' yang diluncurkan tahun 2010. Lewat analisis kajian sinema, dengan pendekatan teori multikulturalisme, terbuka tawaran bagi penonton untuk mengambil bagian dalam interpretasi. Secara khusus interpretasi atas praktek budaya yang tercermin melalui narasi film.
\end{abstract}

Kata kunci: Multikultur di Indonesia, analisis film 3 Hati 2 Dunia 1 Cinta, wacana budaya.

\begin{abstract}
Multicultural issues in Indonesia is a new discourse in a culture that is important in connection with a lot of racial conflicts that occurred lately. Film as an audio visual media has a major role in campaigning for the idea. Therefore, analyzing the film with a multicultural perspective will be a separate view that may be developed in relation to its role in this culture. This article reviews '3 Hearts 2 Worlds 1 Love' a movie which was launched in 2010. Through the analysis of cinema studies, the theoretical approach of multiculturalism, open bids for the audience to take part in the interpretation. In particular the interpretation of cultural practice that is reflected through the film's narrative.
\end{abstract}

Keywords: Multiculture in Indonesia, movie analysis, '3 Hearts 2 Worlds 1 Love', cutural discourse.

\section{Media Audio Visual dalam Budaya}

Saat ini bidang ilmu desain komunikasi visual sedang melebarkan sayapnya dalam rangka menangkap isu budaya dimana fenomena komunikasi visual turut menjadi bagian penting didalamnya. Dengan bantuan teknologi komunikasi terkini kegiatan berkomunikasi secara verbal dan visual dapat dilakukan secara bersamaan melampaui jarak dan waktu. Aplikasi teknologi baru ini dalam banyak bidang kehidupan telah membawa serta berbagai dampak social, yang mempengaruhi pola interaksi masyarakatnya. Tak pelak terjadi banyak gesekan social yang berujung pada konflik. Sebagai media audio visual, filmpun menjadi wacana budaya yang berkembang dalam masyarakat. Menghadirkan film sama dengan menghadirkan sebuah realita yang meskipun nampak seperti sebuah simulakra, telah jadi medium utama dalam perkembangan perfilman itu sendiri, dan dalam kaitannya dengan isu social dalam masyarakat. Oleh karena itu dalam kajian sinema, film seringkali dicermati sebagai pembawa pesan moral tertentu, dan sebagai bagian dari praktek budaya. Film berkontribusi pada perkembangan masyarakat dimana ia hadir. John Hill dalam The Oxford Guide fo Film Studies (1998:xix) melihat bagaimana film direspon oleh penonton sebagai isu penting dimana berbagai pembacaan yang dilakukan terhadapnya akan selalu berhubungan dengan pola social dan identitas budaya sebuah masyarakat. Sehingga kajian sinema menjadi menarik ketika didekati dari teori social yang sedang berkembang.

Di lain pihak pergaulan antar bangsa dan budaya telah menjadi isu global yang tidak terhindarkan. Kemajemukan menjadi bagian normal dalam suatu masyarakat multikultur. Film yang Dianalisa adalah 3 Hati 2 Dunia 1 Cinta. Film ini mengusung sebuah isu besar yang sedang hangat diperbincangkan yaitu multikultur. Memper- 
bincangkan bagaimana film nasional sebagai media audio visual, memberi sumbangan pemikiran mengatasi kemajemukan budaya yang ada dalam masyarakat di Indonesia.

Bahwa semboyan Bhineka Tunggal Ika yang mengikat dasar negara Indonesia, telah mencerminkan pengakuan akan keragaman yang telah diwarisi masyarakat kita. Namun demikian, tidak dapat disangkal, perselisihan bahkan permusuhan kerap muncul akibat keberbedaan yang dimiliki.

\section{Multikulturalisme dan Etika}

\section{Multikulturalisme}

Brian Fay dalam Contemporary Philosophy of Social Science, A Multicultural Approach (1998:34) berpandangan bahwa multikulturalisme menunjuk kepada sesuatu yang krusial dalam dunia kontemporer, dimana masyarakat saling berhubungan dalam berbagai perbedaan. Semua keberagaman harus fokus pada saling pengertian dan hidup dalam lingkungan sosial budaya yang berbeda-beda, atau multukulturalisme bisa disebut sebuah 'perayaan perbedaan'. Apapun bentuk perbedaannya harus dihormati. Sementara William Haviland (1998:289-290) melihat multikulturalisme sebagai pluralisme kebudayaan yang secara antropologis menjadi masa depan umat manusia, daripada kondisi homogen yang tentu lebih sulit diterima semua orang.

Realitanya kita ada di dunia yang didalamnya perbedaan hanyalah sebuah kenyataan hidup yang sederhana, namun usaha sungguh-sungguh masih harus terus dilakukan menghadapi kenyataan ini. Mentalitas harus terus dibangun untuk dapat hidup berdampingan dengan mereka yang berbeda dari kita. Senada dengan hal tersebut Daniel Sparingga dalam buku kumpulan tulisan Etika Multikultural (2003:17) mendefinisikan multikulturalisme sebagai kepercayaan yang menyatakan bahwa kelompok etnik dan budaya dapat hidup berdampingan secara damai dalam prinsip ko-eksistensi, yang ditandai dengan bersedia menghormati budaya lain.

Hidup secara damai dengan sikap penghormatan akan budaya lain itulah yang tidak mudah. Ada banyak sekali aspek yang ikut terlibat. Di tengah berbagai perbedaan, ada kesadaran yang telah dibangun para pendiri bangsa. Dalam hal ini Indonesia punya Binneka Tunggal Ika, yang secara etika normatif mengikat masyarakatnya, dan secara legal ada Pasal 32 (1) UUD 1945 yang telah diamandemen, bahwa Negara memajukan kebudayaan nasional Indonesia di tengah per- adaban dunia dengan menjamin kebebasan masyarakat dalam memelihara dan mengembangkan nilai-nilai budayanya. Tetapi ini bukanlah sebuah jaminan dalam praktek sesungguhnya. Ada banyak konflik yang bersumber dari adanya perbedaan dalam kehidupan bermasyarakat.

Pembahasan tentang multikulturalisme akan juga menyinggung etika dalam multikulturalisme itu sendiri. Sebuah jurnal Filsafat UGM yang ditulis oleh Agus Zubair, menyebutkan etika multikulutralisme sebagai konsep yang mampu mengartikulasikan dimensi kebenaran kultural dengan tidak mematikan pluralitas kultural. Kesadaran budaya berupa penghargaan atas kemajemukan budaya dan tidak bisa dilihat secara parsial, sebab kebudayaan adalah keunikan manusia, yang merupakan keutuhan sistemik dari nilai budaya, pandangan hidup, norma, moral, adat istiadat, hukum, perilaku dan ekspresi kebudayaan. Setiap manusia, secara individual dan sosial, memiliki kondisi dan pengalaman yang berbeda, sehingga norma, perilaku serta ekspresi kebudayaannya akan berbeda juga. Maka konsekuensi kemajemukan tidak terelakkan dari kehidupan manusia. Manusia menjalankan kegiatannya untuk mencapai sesuatu yang bernilai bagi dirinya. Oleh karena itu tidak ada dominasi satu etnik terhadap yang lain dibenarkan. Struktur hirarkis yang mengeksekusi etnik tertentu, menundukkan, mensubordinasi dan menindasnya, harus dihindarkan.

Di sinilah pentingnya dialog dan kemitraan yang secara implisit mengandung komunikasi antar dua pihak yang berbeda, namun setara. Bahwa realitas keagamaan yang majemuk sangat problematis dalam konteks pluralitas Indonesia. Perbedaan agama dan klaim-klaim kebenaran yang diyakininya, telah membuat agama di Indonesia nyaris berada dalam situasi konfliktual, bukan saja terhadap sesama agama, tapi juga terhadap entitas lain semisal pengetahuan ilmiah, sosial, politik, budaya dan sebagainya. (Agus Zubair, Jurnal Filsafat, Agustus 2003, Jilid 34, Nomor 2, 118-19; http://jurnal.filsafat.ugm.ac.id/ index.php/jf/article/viewFile/18/15)

\section{Multikultural di Indonesia}

Isu multikultur di Indonesia lekat dengan isu keagamaan. Hal ini sejalan dengan pemikiran Samuel Hutington dalam Clash Of Civilization (1996). Bahwa kebudayaan di suatu tempat itu ditentukan oleh bahasa, sejarah, institusi, agama, dan identifikasi subyektif masyarakatnya. Dan bahwa sebenarnya konflik antar peradaban di masa depan tidak lagi disebabkan oleh faktorfaktor ekonomi, politik dan ideologi, tetapi justru 
dipicu oleh masalah masalah suku, agama, ras dan antar golongan (SARA). Perbedaan-perbedaan inilah yang menyebabkan konflik yang disebutnya sebagai ethno-religious clash.

Sebuah hasil penelitian mengkonfirmasi dugaan tersebut. Data yang dimuat dalam buku Airlangga Karakter terbitan Universitas Airlangga, hasil survei Setara Institut (Jawa Pos, 30 November 2010), menyebutkan bahwa $44,08 \%$ responden telah merasa tidak nyaman hidup bertetangga dengan yang beragama lain. Keberadaan rumah ibadah agama lain juga tidak disukai. 49,50\% responden menyatakan hal tersebut. Data ini menunjukkan bahwa kehidupan intoleran yang terjadi antar penduduk beda agama kian menguat. Tidak itu saja bertetangga dengan yang berbeda sukupun mulai terlihat berpotensi jadi masalah. Hampir 40\% responden telah tidak merasa nyaman hidup berdampingan dengan yang berbeda suku.

Tabel 1. Ketidaknyamanan atas perbedaan

\begin{tabular}{lcc}
\hline & Suka/setuju Tidak suka/ \\
& $\begin{array}{c}\text { Tidak setuju } \\
\text { tidak }\end{array}$ \\
\hline - Tetangga beda suku & $59,42 \%$ & $39,75 \%$ \\
- Tetangga beda agama & $54,5 \%$ & $44,08 \%$ \\
- Rumah ibadah agama lain & $45 \%$ & $49,50 \%$ \\
di lingkungan & & \\
\hline
\end{tabular}

Data lain terungkap dalam konferensi pers hasil survei Tata Nilai, Impian, Cita-cita Pemuda Muslim di Asia Tenggara yang diadakan GoetheInstitut, The Friedrich Naumann Foundation for Freedom, Lembaga Survei Indonesia dan Merdeka Center for Opinion Research Malaysia. Survei ini diselenggarakan pada 18-26 November 2010 dengan 1496 responden berusia 15-25 tahun, dan berasal dari 33 provinsi. Hasilnya, 47,5\% kaum muda Indonesia memandang diri mereka pertama-tama sebagai orang muslim. Sedangkan yang menganggap mereka pertama-tama orang Indonesia sebanyak 40,8\%. Yang menarik menurut artikel ini, anak-anak muda yang mengutamakan identitas keislamannya ini sebagian besar tinggal di perkotaan. Mapan secara ekonomi dan berpendidikan sampai tingkat universitas. Sementara pemuda desa dengan status ekonomi lebih rendah justru mendominasi kelompok responden yang lebih merasa sebagai orang Indonesia lebih dulu daripada muslim. Nampaknya kehidupan beragama jauh lebih penting daripada rasa kebangsaan. Selanjutnya, sekitar 90,1 \% anak muda juga mengaku tidak mau menikah dengan orang beda agama. Dari 9\% yang menjawab bersedia menikah beda agama, 69 persennya menyatakan syarat bahwa si pasangan harus pindah ke agamanya. Meski begitu, menurut
Direktur Urusan Publik LSI, Burhanuddin Muhtadi, pemikiran konservatif ini tidak sebanding dengan aktivitas keagamaan mereka. Hanya $28,7 \%$ responden yang mengaku selalu salat lima waktu dan hanya 10,8 persen yang membaca atau memahami Quran. (http://id.berita.yahoo.com/ anak-anak-kota-yang-tidak-nasionalis.html).

Betapa kini perbedaan dalam keyakinan semakin berpotensi memicu persoalan kehidupan bermasyarakat. Apakah perbedaan keyakinan lalu memecah masyarakat, atau hidup berdampingan dalam keberbedaan menjadi demikian sulit, membuat kita lebih baik hidup dalam masyarakat yang homogen?

Mencermati berbagai konflik horizontal yang terjadi di Indonesia akhir-akhir ini memperkuat pemikiran di atas. Menyikapi hal ini penting ditumbuhkan kesadaran akan kontribusi pemikiran yang bernuansa membangun kebersamaan, tidak atas persamaan yang dimiliki tetapi justru atas perbedaan yang dimiliki. Inilah isu multikultural yang diusulkan oleh Will Kymlicka, seorang pakar multukultur dari Kanada. Dalam bukunya Multicultur Citizenship (1995) ia menyumbangkan sebuah ide tentang keberagaman yang mungkin hidup dalam suatu masyarakat, tanpa memecah budaya atau identitas yang mengikat para anggotanya. Kymlicka mencoba mengintegrasikan hak-hak minoritas dalam suatu kelompok masyarakat, dengan ide liberal. Sebuah ideology filosofis yang menawarkan bentuk respon atau toleransi terhadap keragaman budaya dan agama, dimana individu sebagai anggota kelompok bisa mendapat penghargaan lebih dalam menentukan nasibnya.

Politik multikultural ini berlawanan dengan politik homogenisasi atas keragaman sosio kultural. F. Budi Hardiman mencontohkan bagaimana kejatuhan Yugoslavia dan Soviet memberi pelajaran berharga tentang hal tersebut. Masyarakat modern semakin sadar akan kondisi masyarakat multikultural yang tersusun dari berbagai macam bentuk kehidupan dan orientasi nilai, atau menjadi suatu negeri dengan banyak 'bangsa', meminjam istilah Geertz. (Kymlicka 2003, ix)

Filosofi multikultur yang terjadi di Indonesia nampaknya lebih pada tataran ide normative. Jelas bukan hal yang mudah dipahami apalagi untuk diterapkan, mengingat kebaruan ide ini bagi banyak orang disini. Tetapi apa yang ditunjukkan dalam film berikut ini memperlihatkan kepekaan visual yang layak dipertimbangkan sebagai kontribusi masyarakat yang penting. 


\section{Film 3 Hati 2 Dunia 1 Cinta}

Film ini diproduksi oleh Mizan Productions, dan disutradarai oleh Benny Setiawan. Tokoh utama pria diperankan oleh Reza Rahadian, sedangkan tokoh utama wanita diperankan oleh Laura Basuki. Berkisah tentang seorang lelaki muslim dan gadis Katolik yang jatuh cinta dan berencana untuk menikah. Namun, kedua orang tua mereka menentang keras. Orang tua mereka tidak setuju, karena menurut keyakinan yang dianut, menikah beda agama tidak legal. Kisah cinta lintas agama dan etnik bercerita tentang seorang pemuda seniman sastra keturunan Arab beragama Islam yang menjalin cinta dengan gadis Katolik etnik China. Hubungan keduanya tak mendapat restu dari orang tua masing-masing. Tapi, sepasang kekasih itu terus berusaha mencari jalan agar cinta mereka menyatu.

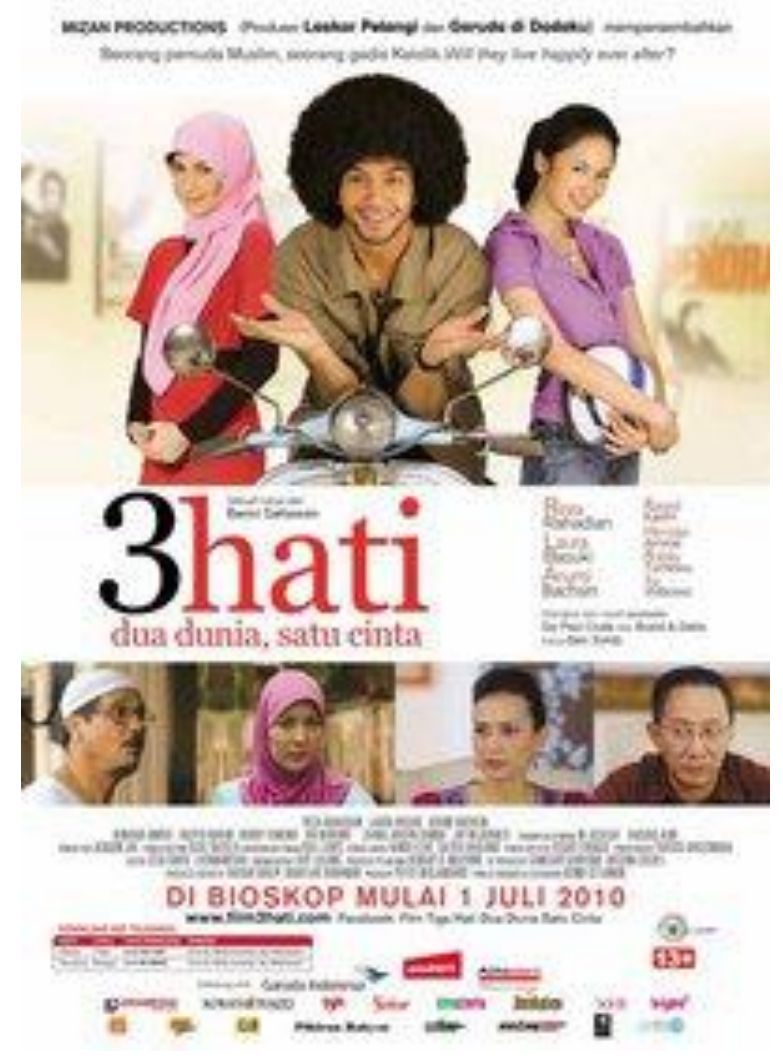

Gambar 1. Poster film.

\section{Pentingnya Sebuah Proses Berpikir, Analisis Film}

Ada beberapa konflik yang mengemuka dalam film 3 Hati 2 Dunia 1 Cinta yang menarik dibahas dalam kaitannya dengan multikulturalisme di Indonesia. Tidak dapat disangkal, alur cerita yang membalut narasi, mengalir alami dalam plot demi plot, membuat penonton ikut merasakan kegelisahan, ketakutan, kesedihan, rasionalitas, di awal hingga pertengahan cerita, hingga secuil kelapangan hati manusia di akhir cerita. Aspek melihat dengan kaca mata circuit of culture yang ditawarkan Sturart Hall, dkk bisa memberi cakrawala yang lebih kaya untuk melihat kode budaya yang dibawa film tersebut. Namun adalah jelas bahwa isu besar film ini adalah isu multkultur yang sedang banyak dibicarakan di Indonesia akhir-akhir ini.

Konflik utama film ini adalah bagaimana hubungan cinta dua orang dengan latar belakang berbeda menimbulkan banyak masalah ketika akan dilanjutkan dalam tradisi lembaga pernikahan. Konflik terbangun dalam latar belakang etnis Arab dan Cina keturunan dengan agama Katolik sebagai kelompok minoritas dan Muslim sebagai mayoritas di Indonesia. Sebagai keluarga terpelajar kelas menengah perkotaan persoalan hubungan berlatar berbeda memang cukup sering terjadi. Berdasarkan pengalaman sebagaimana dituturkan oleh keluarga Adelia (tokoh utama wanita), maupun keluarga Rasyid (tokoh utama pria), tampak jelas ada sejumlah permasalahan yang biasa timbul seputar nikah beda keyakinan, sehingga mereka bisa dikatakan bersikap realistis dengan melihat kenyataan yang ada. Permasalahan ini timbul dalam hubungan antar Adelia dan Rasyid, juga antar keluarga keduanya. Antara memperjuangkan hak pribadi sebagai manusia dan hak pribadi dengan hak kelompok dimana mereka berada.

Bahwa faktor budaya, baik keyakinan (agama) maupun tradisi yang telah turun temurun telah ikut membentuk cara berpikir kedua keluarga besar yang berperan dalam film ini. Tetapi jelas film ini hendak mengatakan kepada penonton akan adanya sebuah konstruksi yang membelenggu manusia yang kemudian melahirkan cara berpikir dan bertindak.

Sebagai makhluk sosial manusia tidak pernah sungguh-sungguh bebas menguasai tubuhnya untuk menentukan hal terbaik baginya. Terdapat gap antara hak individu dengan hak kolektif pada para tokohnya. Ada ideologi atas tubuh yang seringkali turut mengendalikan perilaku dan hubungannya dengan orang lain. Inipun berbasis pada etnis tertentu. Ideologi yang diterima hampir secara mutlak, dan hampir tidak membuka peluang untuk diperbincangkan. Hal ini terlihat dari cara bertutur dan berperilaku para pelakon seperti antara lain yang diperlihatkan Adelia ketika hendak bersalaman dengan Ayah dari Rasyid. Penolakan Ayahnya dengan memandangi tubuh Adelia dari atas ke bawah (dengan sudut pandang kamera). Ini juga terlihat melalui dialog 
antara Rasyid tentang ide warna kopiah. Juga pada saat Rasyid memberi kode kepada Adelia untuk menutup sebuah kancing teratas dari baju yang dikenakannya.

Keragaman masyarakat dan budaya yang sempat diperlihatkan di awal atau pertengahan film ini menunjukkan bentuk keragaman, yang dalam banyak arti masih dapat diperdebatkan. Isu beda agama atau hanya beda keyakinan dalam memandang sebuah kebenaran, yang hampir berujung pada tindakan semena-mena, sebagai sentral cerita film ini, memang lekat dengan berbagai isu multikultur yang merebak. Namun dengan mulus film ini menyajikan sebuah pendekatan komunikasi dua arah mampu mengatasi ketegangan. Dimulai dengan dialog antar pihak yang hendak menyerang rumah Mahdi (salah seorang teman Rasyid), hingga dialog-dialog yang terjadi antara Rasyid dan Adelia, dengan keluarganya masing-masing. Kesaling pemahaman membawa dampak yang lebih baik dalam menjalin hubungan, baik antara kedua tokoh maupun antar tokoh dengan orang tua mereka.

Pada akhir cerita dikisahkan bahwa hubungan pasangan beda agama tersebut tidak diakhiri dalam sebuah lembaga pernikahan, tetapi peluang berhubungan atas dasar penghargaan atas diri kedua tokoh dan pengertian yang dibangun bagi orang-orang dilingkungan mereka, telah membawa mereka pada keputusan di atas, yang tampaknya diambil dengan lapang dada, yang oleh film ditunjukkan diakhiri dengan kebahagiaan melalui tarian Arab yang ditarikan keduanya.

Keperbedaan yang mereka miliki memang membuat konsekuensi tertentu, namun ketika masalah ini dihadapi dengan sikap bijak oleh kedua orang tua tokoh, justru membangun kedasaran kedua tokoh utamanya untuk tidak melanjutkan hubungan mereka ke jenjang pernikahan. Film ini memberi solusi ideologi multikultur yang masih menjadi masalah di Indonesia, bahwa hidup bersama dalam keberagaman belum tentu adalah ide buruk. Tidak perlu semua perbedaaan diakhiri permusuhan (antara ayah Rasyid dan Rasyid), atau diakhiri dengan persatuan (antara Rasyid dan Adelia). Bukan keputusan akhir kedua tokoh yang penting, tetapi proses berpikir dalam pengambilan sikap-sikap sebelumnya, yang dilalui para tokoh ini sebagai konflik pribadi, yang akan menentukan sikap dan keadaan ke depannya (terlihat melalui perubahan sikap kedua orang tua tokoh utama yang berangsur melunak). Karena film ini membuat sebuah tawaran, yang masih sedikit dipertimbangkan dalam setiap pengambilan keputusan tindakan menyangkut multikultur di Indonesia.

\section{Multikultur Indonesia vs Multikultur Kymlicka}

Ide besar film ini adalah pergolakan pemikiran dan pengalaman, lewat dialog-dialog, dan tindakan-tindakan para tokoh dalam film. Lalu pada akhir cerita tokoh-tokoh tersebut memperlihatkan sebuah bentuk apresiasi dan penerimaan atas adanya hak pribadi yang perlu diutamakan. Namun hal ini sama sekali tidak dimaksudkan sebagai sebuah pemaksaan, karena semua diawali dengan dialog. Bahwa selalu ada hak dan regulasi berbeda yang dimiliki oleh kelompok etnis dengan keyakinan mereka masing-masing. Kemudian scene-scene bagian akhir yang memperlihatkan adegan bersalam-salaman antara orang tua kedua tokoh dalam suatu pegelaran puisi, dan menari bersama oleh kedua tokoh, bisa dipandang sebagai bentuk penghargaan atau perayaan atas keberbedaan mereka.

Isu multikultur berupa keterbukaan para tokoh, yang dengan melakukan dialog-dialog, meskipun pendek, cukup padat menyampaikan adanya usaha memahami pihak lain di tengah ekspresi hak-hak individu atau kelompok. Hak individu ditunjukkan oleh tokoh Rasyid dan Adelia, sedangkan hak kelompok etnis atau kelompok tradisi diperlihatkan oleh orang tua mereka berdua. Bahwa sebagai anggota keluarga dari etnis katurunan Arab, Rasyid diharapkan mampu meneruskan budaya dan keyakinan mereka, sekalipun itu bertentangan dengan keinginan pribadinya. Demikian pula dengan Adelia, meskipun tidak secara langsung menentang hubungan anaknya, nampak jelas orang tua Adeliapun mencoba mencari cara untuk memutuskan hubungan anaknya yang dianggap akan mendatangkan banyak kesulitan.

Bila dapat dikatakan sebagai simbol, dengan sebuah penambahan keterbukaan yang terjadi dalam keluarga berlatar belakang Katolik-Cina yang lebih berhasil secara ekonomi, dianggap lebih terbuka, daripada keluarga berlatar belakang Muslim-Arab. Juga dalam memperlakukan anak perempuan dalam tradisi keluarga Arab, hak berekspresi anak perempuan tampak lebih terbatas dan tertutup. Posisinya terhegemoni oleh otoritas laki-laki. Film menunjukkan tokoh ketiga yang diperankan Arumi Bachsin selalu nampak lemah, siap diatur oleh otoritas di atasnya, tertunduk, ada keraguan dalam mengekspresikan dirinya, atau sekedar menyatakan pendapat. Dalam hal ini masih tetap dapat dipertanyakan kebenarannya, seberapa banyakkah perempuan muslim perkotaan yang masih berlaku demikian. Jadi di satu pihak ide keterbukaan atas keberbedaan, tetap diwarnai tindakan mengokohkan 
kaum perempuan di pihak yang lemah. Multikultur yang disampaikan disini memperkuat binari oposisi di satu pihak, sekaligus mengangkat isu keterbukaan, dan sikap moderat anak muda zaman sekarang, yang selalu mempertanyakan keadaan yang bagi sementara orang sudah stabil. Golongan usia muda terlihat lebih fleksibel menghadapi kemungkinan perubahan, dan tidak demikian dengan orang yang lebih tua. Bagi orang tua untuk sampai ke tahap ini dibutuhkan waktu untuk berproses. Namun harus dikatakan bahwa kedua tokoh utama film ini belum tentu menjadi representasi anak muda Indonesia, mengingat gelombang keterbukaan yang datang bersama kemajuan teknologi khususnya media dan telekomunikasi belum lama terjadi.

Sejauh yang dapat teramati film ini menunjukkan tidak adanya perbedaan antara multikultur di Indonesia dengan ide multikultur Kymlicka. Balutan film ini sebetulnya tidak menyajikan hal baru dalam konflik keagamaan di Indonesia, tapi ia tetap potret yang tidak sepenuhnya benar, atau tidak sepenuhnya keliru dalam representasi keberagaman di Indonesia. Yang meskipun dalam balutan komersil, ide cerita ini telah seolah-olah menyederhanakan konflik yang mungkin jauh lebih kompleks. Penyelesaian yang diambil tampak sangat ideal bagi solusi sebuah perbedaan. Tentu ini dapat dikatakan mengingat banyaknya konflik serupa yang terjadi belakangan ini di Indonesia yang berakhir bertolak belakang dengan akhir film ini. Perbedaan cenderung menjadi pemicu konflik, seperti yang dicontohkan para tokohnya.

Meskipun demikian, dengan isu dan kritik yang telah disampaikan diatas, sebuah apresiasi diberikan masyarakat dengan membludaknya penonton. Secara khusus penghargaan diberikan para insan perfilman Indonesia dengan diganjarnya film ini sebagai film terbaik FFI 2010. Film 3 Hati 2 Dunia 1 Cinta selain meraih film dan sutradara terbaik yang menempatkan nama Benny Setiawan, serta pemeran utama pria terbaik yang disabet Reza Rahardian, dan pemeran wanita utama terbaik oleh Laura Basuki, juga mendapatkan penghargaan atas skenario adaptasi (Benny Setiawan), pemeran pendukung pria terbaik (Rasyid Karim) dan tata artistik (Oscar Firdaus) (http://suaramerdeka.com/v1/index.php/read/entertainmen/201 0/12/07/2692/3-Hati-2-Dunia-1-Cinta-Rajai-FFI2010).

\section{Kesimpulan}

Film jelas menjadi arena wacana budaya yang mengangkat eksistensi dan identitas masyarakatnya. Melalui bahasa sinema perspektif multikultur yang dimunculkan dalam film ini mencerminkan pandangan kaum muda yang sedang berproses untuk memahami perbedaan. Secara visual film berhasil mengetengahkan ide multikultur dalam balutan pesan romantisme anak muda. Sekalipun demikian pesan yang disampaikan jelas ditujukan kepada banyak komponen masyarakat dimana keluarga, agama bahkan negara telah menjadi agen perbedaan budaya itu sendiri.

Secara narasi sinematik ada situasi awal yang dibangun, yaitu hubungan kedua tokoh utama yang berbeda latar belakang agama, kemudian dilanjutkan konflik, berupa ketidaksetujuan kedua keluarga besar ketika mengetahui hubungan tersebut, dan diakhiri situasi akhir yang menunjukkan kesadaran kedua tokoh utama untuk tidak melanjutkan hubungan karena adanya perbedaan mereka, meskipun dengan mengabaikan hak pribadi mereka. Konflik yang dimunculkan dan akhir cerita ini dirasa telah menyederhanakan persoalan. Kritik ini dikaitkan dengan keadaan di Indonesia yang nampak lebih kompleks. Persoalan hubungan beda agama lebih dititik beratkan pada konflik keluarga muslim-Arab bukan keluarga Cina-Katolik, yang belum tentu tidak punya masalah sebanyak pihak Muslim-Arab. Ketidak seimbangan ini menjadi faktor keberatan penulis. Faktanya persoalan multikultur yang melibatkan etnis Cina sesungguhnya memiliki aspek lain yang juga mengemuka, seperti isu kecemburuan ekonomi yang telah mengakar di negara kita dan isu minoritas di tengah mayoritas. Ataukah para tokoh ini sama sekali tidak terkena dampaknya? Ini masih sebuah pertanyaan yang perlu dijawab. Nampaknya isu ini menguntungkan pihak CinaKatolik, tetapi tidak cukup menjawab persoalan yang ada ketika dihadapkan pada masalah hubungan pasangan beda agama dan etnis dengan semua latar belakang tradisi dan persoalan sosial yang tetap menyertai mereka. Negara kita tetap punya masalah kecemburuan sosial yang tidak teratasi secara mudah atau seketika. Bila hal ini bisa ikut tersampaikan setidaknya fakta sosial yang dirasa, tidak seolah-olah dianggap tidak ada.

Kedewasaan yang ditunjukkan para tokoh utama tentu sangat baik. Penulis setuju dengan akhir film yang menarik, dengan menunjukkan perayaan atas perbedaan. Budaya tetap cair, sehingga percampuran dan akulturasi bukan sebuah kesalahan, dan sejauh ini bukan sebuah pemaksaan. Semua ini diproses dengan waktu, yang sayangnya akhir dalam film dibuat sangat sederhana, padahal para tokoh ini telah mengambil sikap yang sangat dewasa dalam rentang umur mereka ketika dihadapkan pada isu perbedaan budaya di antara mereka. 


\section{Daftar Pustaka}

Fay, Brian. (1998). Contemporary Philosophy of Social Science, A Multicultural Approach. Massachussets: Blackwell Publisher Ltd.

Haviland, William A. (1988). Antropologi (edisi keempat, jilid 2, terj.) Jakarta: Erlangga.

Hill, John. (1998). The Oxford Guide fo Film Studies. New York:Oxford University Press. 1998.

Huntington, Samuel P., Ismail, M. Sadat, Ruslani. (2003). Benturan Antar Peradaban Dan Masa Depan Politik Dunia. Yogyakarta: Qalam.

Kymlicka, Will. (2003). Kewarganegaraan Multikultural. Jakarta: LP3ES.
Achmad Charris Zubair, Membangun Kesadaran Etika Multikulturalisme di Indonesia, Jurnal Filsafat UGM, Agustus 2003, Jilid 34, Nomor 2 (http://jurnal.filsafat.ugm.ac.id/index.php/jf/ article/viewFile/18/15)

http://agama.kompasiana.com/2010/07/14/film-3hati-2-dunia-1-cinta-itu-solusi-pernikahanbeda-agama

http://id.berita.yahoo.com/anak-anak-kota-yangtidak-nasionalis.html

http://suaramerdeka.com/v1/index.php/read/ente rtainmen/2010/12/07/2692/3-Hati-2-Dunia1-Cinta-Rajai-FFI-2010 